\title{
Perbaikan Proses Bisnis Penyusunan Rencana Kerja DISKOPERINDAG Menggunakan Metode Business Process Improvement Berdasarkan PERMENDAGRI Nomor 54 Tahun 2010 Serta Klausul 7.3 ISO 9001:2008
}

\author{
Silvi Rushanti Widodo ${ }^{(1)}$, Yati Rohayati ${ }^{(2)}$, Atya Nur Aisha ${ }^{(3)}$ \\ ${ }^{(1,2,3)}$ Jurusan Teknik Industri, Universitas Telkom, Bandung \\ Email : rushantisilvi@ gmail.com ${ }^{(1)}$
}

\begin{abstract}
Abstrak
DISKOPERINDAG Kabupaten Bandung memiliki peranan dalam penyusunan perencanaan daerah, salah satunya adalah penyusunan Renja. Dalam kondisi aktual rencana kerja yang disusun oleh DISKOPERINDAG memiliki permasalahan yakni ketidak tepatan dalam penyusunan Renja. Penelitian ini bertujuan untuk merancang proses bisnis usulan dalam penyusunan Renja. Metode perbaikan proses bisnis yang digunakan adalah Business Process Improvement (BPI). Perbaikan proses bisnis dilakukan dengan mengidentifikasi gap proses bisnis penyusunan Renja aktual dengan alur perencanaan Renja berdasarkan PERMENDAGRI Nomor 54 Tahun 2010 dan persyaratan klausul 7.3 ISO 9001:2008. Hasil analisis gap akan menjadi masukkan untuk analisis aktivitas yang dikelompokkan menjadi RVA, BVA dan NVA. Perbaikan proses bisnis dilakukan dengan mengeliminasi aktivitas NVA, meminimasi aktivitas BVA dan melakukan streamlining pada aktivitas RVA. Pada tahap pengumpulan data diperoleh 11 proses bisnis penyusunan Renja aktual dan 21 aktivitas berdasarkan PERMENDAGRI. Hasil gap antara proses bisnis aktual dan proses bisnis berdasarkan PERMENDAGRI terdapat 31 proses. Hasil analisis aktivitas menunjukkan terdapat 12 aktivitas RVA, 19 BVA, 0 NVA. Tools perbaikan proses bisnis yang digunakan antara lain value-added assessment, simplification, dan duplication elimination. Berdasarkan hasil perbandingan waktu efisiensi, pada proses bisnis eksisting 19,14\%, sementara pada proses bisnis usulan 21,88\%. Usulan proses bisnis penyusunan Renja menjadi masukkan dalam penyusunan SOP dan instruksi kerja.
\end{abstract}

Kata Kunci: Business Process Improvement, Klausul 7.3 ISO 9001:2008, PERMENDAGRI Nomor 54 Tahun 2010, Renja, Standard Operating Procedure.

\begin{abstract}
DISKOPERINDAG Bandung Regency has a role in the preparation of regional planning, one of which is the preparation of Renja. In the actual condition the work plan compiled by DISKOPERINDAG has a problem namely inaccuracy in the preparation of Renja. This study aims to design the proposed business processes in the preparation of Renja. The business process improvement method used is Business Process Improvement (BPI). Business process improvement is carried out by identifying business process gaps in the preparation of the actual Renja with the Renja planning flow based on PERMENDAGRI Number 54 of 2010 and the requirements of clause 7.3 ISO 9001: 2008. The results of the gap analysis will be entered for analysis of activities grouped into RVA, BVA and NVA. Business process improvement is done by eliminating NVA activities, minimizing BVA activities and streamlining RVA activities. At the data collection stage, 11 business processes were developed for the
\end{abstract}


actual Renja and 21 activities based on PERMENDAGRI. The results of the gap between the actual business processes and business processes based on PERMENDAGRI, there are 31 processes. The results of the activity analysis showed there were 12 RVA activities, 19 BVA, 0 NVA. Business process improvement tools used include value-added assessment, simplification, and duplication elimination. Based on the results of the comparison of the efficiency time, the existing business processes $19.14 \%$, while the proposed business processes $21.88 \%$. The proposed business process for the preparation of Renja is included in the preparation of SOPs and work instructions.

Keyword : Business Process Improvement, Clause 7.3 ISO 9001: 2008, PERMENDAGRI Number 54 of 2010, Renja, Standard Operating Procedure.

\section{Pendahuluan}

Perencanaan strategis adalah proses rencana jangka panjang pada sebuah organisasi. Perencanaan ini bertujuan untuk menggali gagasan, pengambilan langkah, dan pemantauan dari sebuah kesuksesan atau kegagalan suatu kegiatan untuk menentukan strategi dan mencapai tujuan organisasi dimasa yang akan datang.

Manfaat dari perencanaan strategis adalah berguna bagi perencanaan untuk perubahan dalam lingkungan dinamik yang lengkap. Perencanaan strategis berguna untuk pengelolaan hasil, sebagai alat manajerial yang penting, berorientasi masa depan, mampu beradaptasi, penting untuk mendukung kebutuhan pelanggan, dan mempromosikan komunikasi [1], [2], [3].

Perencanaan stategis juga dilakukan dalam lingkup pemerintahan. Salah satu dinas yang menjalankan perencanaan strategis adalah Dinas Koperasi, UKM, Perindustrian, dan Perdagangan yang selanjutnya disingkat dengan DISKOPERINDAG yang terdapat di Kabupaten Bandung.

DISKOPERINDAG adalah salah satu dinas yang terdapat di Kabupaten Bandung yang mempunyai tugas yaitu melaksanakan urusan pemerintah daerah bidang koperasi, UKM, perindustrian dan perdagangan [4], [5]. Dinas ini menjalankan peran yakni pembuatan Renja untuk semua bidang dalam DISKOPERINDAG yang nantinya akan dilaporkan kepada pihak BAPPEDA yang berperan sebagai penerima input Renja DISKOPERINDAG . Sesuai dengan Tabel 1 bahwa jenis dokumen perencanaan terdapat Renja dimana Renja dinas perlu dievaluasi agar dapat mencapai visi, misi, dan program Kepala Daerah yang tercantum dalam Peraturan Daerah Kabupaten Bandung Nomor 11 Tahun 2011 tentang RPJMD Kabupaten Bandung.

Tabel 1 Jenis Dokumen Perencanaan

\begin{tabular}{|c|c|c|c|}
\hline No & Dokumen Perencanaan & Jangka Waktu & Pelaksana \\
\hline 1 & RPJPD & 25 tahun & BAPPEDA \\
\hline 2 & RPJMD & 5 tahun & BAPPEDA \\
\hline 3 & Renstra & 5 tahun & Dinas \\
\hline 4 & RKPD & 1 tahun & BAPPEDA \\
\hline 5 & Renja & 1 tahun & Dinas \\
\hline
\end{tabular}

Tabel 1 adalah jenis dokumen perencanaan dimana menurut PERMENDAGRI Nomor 54 Tahun 2010, alur penyusunan Renja diawali dengan BAPPEDA menyusun RPJPD kabupaten yang dilaksanakan setiap 25 tahun sekali. RPJPD tersebut digunakan untuk menjadi acuan menyusun RPJMD yang disusun setiap 5 tahun sekali. Tiap-tiap bidang dibawah naungan BAPPEDA termasuk salah satunya adalah DISKOPERINDAG diwajibkan untuk menyusun Renstra tiap 5 tahun sekali dimana Renstra tersebut digunakan sebagai acuan pembuatan Renja yang disusun tiap satu tahun sekali. Renja yang telah disusun oleh masing-masing dinas akan dikumpulkan oleh pihak BAPPEDA untuk menyusun RKPD. Renstra dan Renja yang telah dibuat nantinya akan menjadi acuan kegiatan untuk 
masing-masing dinas.

Berdasarkan hasil wawancara yang telah dilakukan kepada Kepala Subbidang Perencanaan Pembangunan Ekonomi Badan Perencanaan Pembangunan Daerah Kabupaten Bandung yang berperan sebagai penerima input Renja dari DISKOPERINDAG, terdapat permasalahan dalam DISKOPERINDAG Kabupaten Bandung yang harus segera diselesaikan yakni terjadi ketidaktepatan waktu dalam penyusunan Renja. Renja yang seharusnya disusun selama 6,5-7 bulan mengalami keterlambatan hingga 8 bulan sehingga BAPPEDA mengalami kesulitan ketika akan melakukan evaluasi terhadap penetapan dan perumusan program yang telah disusun DISKOPERINDAG. Selain itu, ketidaktepatan penyusunan Renja juga berdampak pada penyusunan RKPD yang dilakukan oleh BAPPEDA.

Salah satu contoh dari ketidaktepatan penyusunan Renja adalah pada proses pembentukan tim penyusun Renja [6], [7]. Pada timeline seharusnya pembentukan tim penyusun Renja dimulai pada bulan Desember, namun pada kondisi aktual pembentukan tim dimulai pada bulan Februari. Tabel 2 adalah timeline penyusunan Renja dan Gambar 1 adalah contoh dokumen kondisi aktual surat perintah pembentukan tim penyusun Renja [8], [9].

Tabel 2 Timeline Penyusunan Renja

\begin{tabular}{|c|c|c|c|c|c|c|c|c|c|c|c|c|c|c|c|c|c|c|c|c|c|}
\hline \multirow{2}{*}{ No. } & \multirow{2}{*}{ hapan Perencanaan dan Penganggaran Tahunan Daer } & \multicolumn{2}{|c|}{ Desember } & \multicolumn{3}{|c|}{ Januari } & \multicolumn{4}{|c|}{ Februari } & \multicolumn{2}{|c|}{ Maret } & \multicolumn{3}{|c|}{ April } & \multicolumn{3}{|c|}{ Mei } & \multicolumn{3}{|c|}{ Juni } \\
\hline & & \begin{tabular}{l|l|}
$\mathrm{I}$ & II \\
\end{tabular} & & $\mathrm{I}$ & \begin{tabular}{|l|l|l} 
II & I \\
\end{tabular} & IIIIV & I & II & \begin{tabular}{|l|l|l|l|l|l|} 
III & I \\
\end{tabular} & IV & \begin{tabular}{|l|l|} 
I & II \\
\end{tabular} & IIIIIV & & II & \begin{tabular}{l|l} 
III & IV \\
\end{tabular} & I & II & III IV & & & IIIIV \\
\hline 1 & Pembentukan tim penyusun SKPD & & & & & & & & & & & & & & & & & & & & \\
\hline 2 & Penyusunan rancangan awal Renja SKPD & & & & & & & & & & & & & & & & & & & & \\
\hline 3 & Musrenbang Desa/Kelurahan & & & & & & & & & & & & & & & & & & & & \\
\hline 4 & Lanjutan penyusunan rancangan Renja SKPD & & & & & & & & & & & & & & & & & & & & \\
\hline 5 & Musrenbang Kecamatan & & & & & & & & & & & & & & & & & & & & \\
\hline 6 & Pembahasan rancangan Renja SKPD pada Forum SKPD & & & & & & & & & & & & & & & & & & & & \\
\hline 7 & Penyusunan rancangan RKPD Kabupaten/Kota & & & & & & & & & & & & & & & & & & & & \\
\hline 8 & Pelaksanaan Musrenbang RKPD Kabupaten/Kota & & & & & & & & & & & & & & & & & & & & \\
\hline 9 & Perumusan rancangan akhir RKPD Kabupaten/Kota & & & & & & & & & & & & & & & & & & & & \\
\hline 10 & Penetapan Perkada RKPD Kabupaten/Kota & & & & & & & & & & & & & & & & & & & & \\
\hline 11 & Penetapan Renja SKPD & & & & & & & & & & & & & & & & & & & & \\
\hline
\end{tabular}

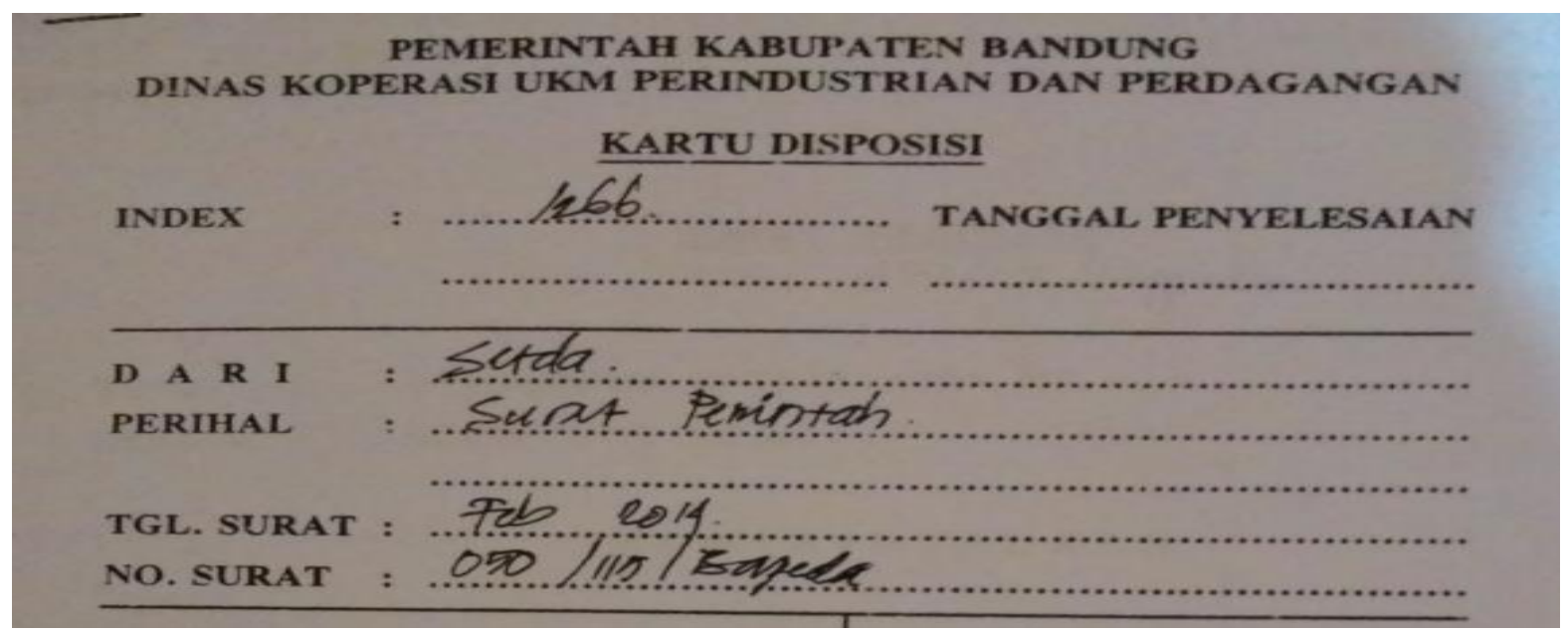

Gambar 1 Contoh Dokumen Kondisi Aktual Pembentukan Tim Penyusun Renja

Permasalahan ketidaktepatan penyusunan Renja akan dianalisis menggunakan 5 Why's untuk mengidentifikasi permasalahan yang terjadi. Tabel 3 adalah hasil analisis dari permasalahan ketidaktepatan penyusunan Renja DISKOPERINDAG. Analisis menggunakan faktor 5M, yakni man, machine, method, material, dan money [10]. 
Tabel 35 Why's Permasalahan Ketidaktepatan Penyusunan Renja

\begin{tabular}{|c|c|c|c|c|c|c|}
\hline No. & Permasalahan & Man & Machine & Method & Material & Money1 \\
\hline 1 & $\begin{array}{l}\text { Mengapa terjadi } \\
\text { ketidaktepatan } \\
\text { penyusunan } \\
\text { Renja? }\end{array}$ & & & & $\begin{array}{c}\text { Input } \\
\text { dokumen } \\
\text { tidak } \\
\text { tepat } \\
\text { waktu }\end{array}$ & \\
\hline 2 & $\begin{array}{c}\text { Mengapa input } \\
\text { dokumen tidak } \\
\text { tepat waktu? }\end{array}$ & & & $\begin{array}{l}\text { Tidak } \\
\text { mempun } \\
\text { yai SOP }\end{array}$ & & \\
\hline 3 & $\begin{array}{c}\text { Mengapa tidak } \\
\text { mempunyai SOP? }\end{array}$ & $\begin{array}{l}\text { Pegawai tidak } \\
\text { mengerti proses } \\
\text { yang benar }\end{array}$ & & & & \\
\hline 4 & $\begin{array}{l}\text { Mengapa pegawai } \\
\text { tidak mengerti } \\
\text { proses vang benar? }\end{array}$ & $\begin{array}{c}\text { Pegawai tidak } \\
\text { paham dengan } \\
\text { PERMENDAGRI }\end{array}$ & & & & \\
\hline 5 & $\begin{array}{c}\text { Mengapa } \\
\text { karyawan tidak } \\
\text { paham } \\
\text { PERMENDAGRI? }\end{array}$ & & $\begin{array}{c}\text { Pada } \\
\text { PERMENDAGRI } \\
\text { tidak terdapat } \\
\text { langkah-langkah } \\
\text { pengerjaan untuk } \\
\text { setiap prosesnya }\end{array}$ & & & \\
\hline
\end{tabular}

Berdasarkan hasil analisis dengan menggunakan 5 Why's maka didapatkan permasalahan dalam penyusunan Renja berawal dari input dokumen untuk proses selanjutnya mengalami keterlambatan dikarenakan tidak ada SOP yang menjamin waktu proses dari setiap prosesnya. Tidak adanya SOP penyusunan Renja yang dibuat karena pegawai DISKOPERINDAG yang susah untuk memahami PERMENDAGRI. Dalam PERMENDAGRI sudah terdapat langkah-langkah dalam penyusunan Renja namun masih kurang jelas karena tidak terdapat langkah-langkah yang lebih detail dari setiap prosesnya.

Berdasarkan hasil analisis menggunakan 5 Why's, ketidaktepatan DISKOPERINDAG dalam penyusunan Renja selanjutnya akan digambarkan penyebabnya menggunakan diagram sebab akibat yang diperlihatkan pada Gambar 2. Penyebab ketidaktepatan perencanaan diakibatkan oleh empat faktor yakni man, method, machine, dan material [11],[12], [13].

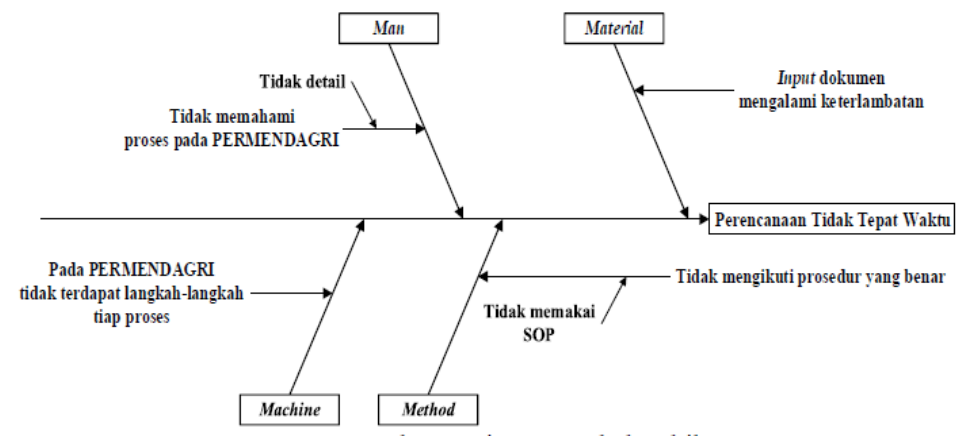

Gambar 2 Diagram Sebab-Akibat

Sesuai dengan Gambar 2 bahwa dilihat dari segi material senyebab ketidaktepatan perencanaan adalah input dokumen dari proses sebelumnya yang juga mengalami keterlambatan sehingga prosesproses yang lain juga menjadi tidak tepat waktu. 
Penyebab kedua dilihat dari segi metode adalah proses yang dilaksanakan kurang tepat karena tidak mengikuti prosedur yang benar diakibatkan karena tidak mempunyai SOP sehingga setiap proses yang dilakukan tidak ada panduannya. Tujuan diadakannya SOP adalah untuk memberikan panduan bagi seluruh instansi pemerintah pusat dan daerah dalam mengidentifikasi, menyusun, mendokumentasikan, mengembangkan, memonitor, serta mengevaluasi kegiatan sesuai dengan tugas dan fungsi aparatur pemerintahan.

Penyebab selanjutnya dilihat dari faktor man atau pegawai DISKOPERINDAG adalah tidak mengerti prosedur penyusunan Renja yang baik dan benar sesuai dengan PERMENDAGRI Nomor 54 Tahun 2010 karena proses pada PERMENDAGRI yang tidak detail sehingga pegawai melaksanakan proses sesuai dengan yang mereka pahami.

Penyebab keempat dilihat dari segi machine atau proses pada PERMENDAGRI Nomor 54 Tahun 2010 yang dijadikan acuan dalam penyusunan Renja kurang detail dalam memberikan langkah-langkah pengerjaan untuk setiap prosesnya. Prosedur adalah suatu urut-urutan pekerjaan kerani (clerical), biasanya melibatkan beberapa orang dalam satu bagian atau lebih, disusun untuk menjamin adanya perlakuan.

Oleh karena itu, dalam Focus Group Discussion yang telah dilakukan bersama pimpinan setiap bidang dalam DISKOPERINDAG dan Kepala Subbidang Perencanaan Pembangunan Ekonomi Badan Perencanaan Pembangunan Daerah Kabupaten Bandung, DISKOPERINDAG mempunyai target output yang digunakan untuk menyelesaikan permasalahan tersebut [14]. Target output-nya adalah dibuatnya Standard Operating Procedures (SOP) yang sesuai dengan peraturan pemerintah yang nantinya akan digunakan oleh DISKOPERINDAG untuk memenuhi tugas . Sekaligus proses yang disesuaikan dengan persyaratan klausul 7.3 ISO 9001:2008 tentang desain dan pengembangan karena proses penyusunan Renja berkaitan dengan proses perencanaan dimana memerlukan input, output, proses verifikasi dan validasi, serta kontrol perubahan desain untuk menjaga kesesuaian proses agar diselesaikan dengan benar dan tepat waktu serta memberikan keunggulan yang kompetitif.

Dalam penelitian ini berfokus pada perbaikan proses bisnis penyusunan Renja DISKOPERINDAG yang hasilnya disajikan dalam bentuk SOP. Tahap ini penting untuk dilakukan karena sebagai prosesnya menyangkut penyelenggaraan forum SKPD yang merupakan wadah penampungan dan penjaringan aspirasi masyarakat.

\section{Metode Penelitian}

Dalam penelitian ini, fokus terhadap penyusunan Renja DISKOPERINDAG dimana tahap pertama yang dilakukan adalah mengidentifikasi proses bisnis aktual yang terdapat pada penyusunan Renja DISKOPERINDAG dengan PERMENDAGRI Nomor 54 Tahun 2010 [15], [16], [17], [18]. Identifikasi dilakukan untuk melihat apakah terdapat gap antara kedua hal tesebut. Gap yang telah teridentifikasi akan dibuat proses dengan hasil silang antara proses aktual dengan proses yang sesuai dengan PERMENDAGRI Nomor 54 Tahun 2010. Hasil silang akan disesuaikan dengan pemenuhan klausul 7.3 ISO 9001:2008 yang akhirnya didapatkan proses bisnis yang sesuai dengan PERMENDAGRI Nomor 54 Tahun 2010 dan klausul 7.3 ISO 9001:2008. Dengan menggunakan metode BPI akan dilakukan analisa setiap aktivitas dalam setiap proses bisnis yang ada dan mengelompokkan kedalam RVA, BVA, dan NVA [19],[20],[21], [22]. Tahap kedua adalah melakukan streamlining terhadap hasil analisa aktivitas yang dilakukan. Proses bisnis yang sudah sesuai didokumentasikan dengan SOP sehingga SOP yang dirancang sudah sesuai dengan peraturan pemerintah dan requirement klausul 7.3 ISO 9001:2008 yang efektif dan efisien.

\section{Hasil dan Pembahasan}

\section{Proses Bisnis Aktual}

Proses bisnis aktual penyusunan Renja ditentukan dari timeline penyusunan Renja DISKOPERINDAG dan dapat dilihat pada tabel 4. 
Tabel 4 Proses Bisnis Aktual

\begin{tabular}{|c|c|}
\hline \multirow{4}{*}{ Proses } & Pembentukan tim penyusun Renja SKPD \\
\cline { 2 - 3 } & Penyusunan rancangan awal Renja SKPD. \\
\cline { 2 - 3 } & Musrenbang Desa/ Kelurahan \\
\cline { 2 - 3 } & Lanjutan penyusunan rancangan Renja SKPD \\
\cline { 2 - 3 } & Musrenbang Kecamatan \\
\cline { 2 - 3 } & Pembahasan rancangan Renja SKPD pada Forum SKPD. \\
\cline { 2 - 3 } & Penyusunan rancangan RKPD Kabupaten/ Kota \\
\cline { 2 - 3 } & Pelaksanaan Musrenbang RKPD Kabupaten/ Kota \\
\cline { 2 - 2 } & Perumusan rancangan akhir RKPD Kabupaten/ Kota \\
\hline
\end{tabular}

Proses Bisnis Menurut PERMENDAGRI Nomor 54 Tahun 2010

Proses bisnis penyusunan Renja menurut PERMENDAGRI Nomor 54 Tahun 2010 dan dapat dilihat pada Tabel 5.

Tabel 5 Proses Bisnis Menurut PERMENDAGRI

\begin{tabular}{|c|l|}
\hline No & \multicolumn{1}{|c|}{ Proses } \\
\hline 1 & Pembentukan tim penyusun Renja. \\
\hline 2 & Orientasi penyusun Renja. \\
\hline 3 & Penyusunan agenda kerja. \\
\hline 4 & Mengumpulkan data dan informasi. \\
\hline 5 & Mengolah data dan informasi. \\
\hline 6 & Menganalisis gambaran pelayanan SKPD. \\
\hline 7 & Melakukan review hasil pelaksanaan Renja SKPD tahun lalu berdasarkan \\
\hline 8 & Renstra SKPD. \\
\hline 9 & Menelaah rancangan awal RKPD. \\
\hline 10 & Merumuskan tujuan dan sasaran Renja. \\
\hline 11 & Menelaah usulan program/ kegiatan dari masyarakat. \\
\hline 12 & Merumuskan kegiatan prioritas. \\
\hline 13 & Menyajikan dokumen awal rancangan Renja SKPD. \\
\hline 14 & Musrenbang desa/ kelurahan. \\
\hline 15 & Lanjutan penyusunan rancangan Renja SKPD. \\
\hline 16 & Musrenbang kelurahan. \\
\hline 17 & Menelaah kebijakan nasional. \\
\hline 18 & Menyempurnakan rancangan Renja SKPD. \\
\hline 19 & Pembahasan forum SKPD. \\
\hline 20 & Menyesuaikan dokumen rancangan Renja SKPD. \\
\hline 21 & Menyiapkan forum SKPD. \\
\hline 22 & Menyelenggarakan forum SKPD. \\
\hline 23 & Pembahasan rancangan Renja SKPD pada forum SKPD. \\
\hline 24 & Penyusunan rancangan RKPD kabupaten/ kota. \\
\hline 25 & Pelaksanaan Musrenbang RKPD kabupaten/ kota. \\
\hline 26 & Perumusan rancangan akhir RKPD kabupaten/ kota. \\
\hline 27 & Penetapan Perkada RKPD kabupaten/ kota. \\
\hline 28 & Verifikasi rancangan Renja SKPD dengan RKPD. \\
\hline
\end{tabular}


29 Pengesahan Renja SKPD.

30 Penetapan Renja SKPD.

\section{Identifikasi Gap Proses Bisnis Aktual dan Proses Bisnis Menurut PERMENDAGRI Nomor 54 Tahun 2010}

Pada penelitian ini menghasilkan hasil identifikasi gap antara proses bisnis aktual dan proses bisnis yang sesuai dengan PERMENDAGRI Nomor 54 Tahun 2010.

Tabel 6 Identifikasi Gap Proses Bisnis Aktual dan Proses Bisnis Menurut PERMENDAGRI Nomor 54 Tahun 2010

\begin{tabular}{|c|c|c|c|}
\hline $\begin{array}{c}\text { Kondisi } \\
\text { Aktual }\end{array}$ & Kondisi Ideal & Gap & Keterangan \\
\hline $\begin{array}{l}\text { Pembentukan } \\
\text { tim penyusun } \\
\text { Renja }\end{array}$ & $\begin{array}{l}\text { Pembentukan } \\
\text { tim penyusun } \\
\text { Renja }\end{array}$ & - & - \\
\hline - & $\begin{array}{l}\text { Orientasi } \\
\text { mengenai } \\
\text { Renja SKPD }\end{array}$ & $\begin{array}{l}\text { Dalam kondisi aktual } \\
\text { tidak terdapat proses } \\
\text { orientasi mengenai Renja } \\
\text { SKPD }\end{array}$ & $\begin{array}{l}\text { Dilakukan penambahan } \\
\text { proses orientasi mengenai } \\
\text { Renja SKPD }\end{array}$ \\
\hline- & $\begin{array}{l}\text { Penyusunan } \\
\text { agenda kerja }\end{array}$ & $\begin{array}{l}\text { Dalam kondisi aktual } \\
\text { tidak terdapat proses } \\
\text { penyusunan agenda kerja }\end{array}$ & $\begin{array}{l}\text { Dilakukan penambahan } \\
\text { proses penyusunan } \\
\text { agenda kerja }\end{array}$ \\
\hline - & $\begin{array}{l}\text { Mengumpulkan } \\
\text { data dan } \\
\text { informasi }\end{array}$ & $\begin{array}{l}\text { Dalam kondisi aktual } \\
\text { tidak terdapat proses } \\
\text { mengumpulkan data dan } \\
\text { informasi }\end{array}$ & $\begin{array}{l}\text { Dilakukan penambahan } \\
\text { proses mengumpulkan } \\
\text { data dan informasi }\end{array}$ \\
\hline - & $\begin{array}{l}\text { Mengolah data } \\
\text { dan informasi }\end{array}$ & $\begin{array}{l}\text { Dalam kondisi aktual } \\
\text { tidak terdapat proses } \\
\text { mengolah data dan } \\
\text { informasi }\end{array}$ & $\begin{array}{l}\text { Dilakukan penambahan } \\
\text { proses mengolah data dan } \\
\text { informasi }\end{array}$ \\
\hline
\end{tabular}

\section{Identifikasi Pemenuhan ISO 9001:2008 Klausul 7.3}

Pemenuhan persyaratan ISO adalah untuk menjaga konsistensi proses seperti yang telah dijelaskan pada latar belakang. Tabel 7menjelaskan tentang pemenuhan persyaratan ISO 9001:2008 klausul 7.3 tentang desain dan pengembangan karena proses penyusunan Renja berkaitan dengan proses perencanaan [23], [24].

Tabel 7 Identifikasi Pemenuhan ISO 9001:2008 Klausul 7.3

\begin{tabular}{|c|c|c|}
\hline Klausul & Persyaratan & Kondisi \\
\hline 7.3 & \multicolumn{2}{|c|}{ Desain Pengembangan } \\
\hline 7.3 .1 & Perencanaan Desain dan Pengembangan & Terpenuhi \\
\hline 7.3 .2 & Masukan Desain dan Pengembangan & Terpenuhi \\
\hline 7.3 .3 & Keluaran Desain dan Pengembangan & Terpenuhi \\
\hline
\end{tabular}

Tabel 7 Identifikasi Pemenuhan ISO 9001:2008 Klausul 7.3 (Lanjutan)

\begin{tabular}{|c|l|c|}
\hline Klausul & \multicolumn{1}{|c|}{ Persyaratan } & Kondisi \\
\hline 7.3 .4 & Tinjauan Desain dan Pengembangan & Terpenuhi \\
\hline 7.3 .5 & Verifikasi Desain dan Pengembangan & Tidak Terpenuhi \\
\hline 7.3 .6 & Validasi Desain dan Pengembangan & Tidak Terpenuhi \\
\hline 7.3 .7 & Pengendalian Perubahan Desain dan Pengembangan & Terpenuhi \\
\hline
\end{tabular}




\section{Hasil Sinkronisasi Gap}

Proses bisnis penyusunan Renja dilakukan sinkronisasi gap antara kondisi aktual dan kondisi yang sesuai dengan PERMENDAGRI Nomor 54 Tahun 2010 serta ISO 9001:2008 dan hasilnya didapatkan 30 proses penyusunan Renja. Setelah itu, akan dilakukan analisa aktivitas untuk mengetahui proses yang tida memberikan nilai tambah dan akan dilakukan eliminasi [23],[24], [25].

Tabel 8 Hasil Sinkronisasi Gap

\begin{tabular}{|c|l|c|c|}
\hline No & \multicolumn{1}{|c|}{ Proses } & $\begin{array}{c}\text { Waktu } \\
\text { Proses }\end{array}$ & $\begin{array}{c}\text { Analisa } \\
\text { Aktivitas }\end{array}$ \\
\hline 1 & Pembentukan tim penyusun Renja. & 10 jam & RVA \\
\hline 2 & Orientasi penyusun Renja. & 5 jam & BVA \\
\hline 3 & Penyusunan agenda kerja. & 2 jam & BVA \\
\hline 4 & Mengumpulkan data dan informasi. & 18 jam & BVA \\
\hline 5 & Mengolah data dan informasi. & 12 jam & BVA \\
\hline 6 & Menganalisis gambaran pelayanan SKPD. & 22 jam & RVA \\
\hline 7 & Melakukan review hasil pelaksanaan Renja SKPD tahun & 16 jam & RVA \\
\hline 8 & lalu berdasarkan Renstra SKPD. & 24 jam & RVA \\
\hline 9 & Menelaah rancangan awal RKPD. & 27 jam & RVA \\
\hline 10 & Merumuskan tujuan dan sasaran Renja. & 16 jam & RVA \\
\hline 11 & Menelaah usulan program/ kegiatan dari masyarakat. & 15 jam & RVA \\
\hline 12 & Merumuskan kegiatan prioritas. & 13 jam & BVA \\
\hline 13 & Menyajikan dokumen awal rancangan Renja SKPD. & 56 jam & BVA \\
\hline 14 & Verifikasi kelengkapan dokumen Renja. & 5 Jam & BVA \\
\hline 15 & Musrenbang desa/ kelurahan. & 50 jam & RVA \\
\hline 16 & Lanjutan penyusunan rancangan Renja SKPD. & 40 jam & BVA \\
\hline 17 & Musrenbang kelurahan. & 50 jam & RVA \\
\hline 18 & Menelaah kebijakan nasional. & 3 jam & RVA \\
\hline 19 & Menyempurnakan rancangan Renja SKPD. & 16 jam & BVA \\
\hline 20 & Pembahasan forum SKPD. & 31 jam & BVA \\
\hline 21 & Menyesuaikan dokumen rancangan Renja SKPD. & 132 jam & BVA \\
\hline 22 & Menyiapkan forum SKPD. & 41 jam & BVA \\
\hline 23 & Menyelenggarakan forum SKPD. & 5 jam & RVA \\
\hline 24 & Pembahasan rancangan Renja SKPD pada forum SKPD. & 80 jam & BVA \\
\hline 25 & Penyusunan rancangan RKPD kabupaten/ kota. & 80 jam & BVA \\
\hline 26 & Pelaksanaan Musrenbang RKPD kabupaten/ kota. & 80 jam & BVA \\
\hline 27 & Perumusan rancangan akhir RKPD kabupaten/ kota. & 320 jam & BVA \\
\hline 28 & Penetapan Perkada RKPD kabupaten/ kota. & 40 jam & BVA \\
\hline 29 & Verifikasi rancangan Renja SKPD dengan RKPD. & 17 jam & BVA \\
\hline 30 & Pengesahan Renja SKPD. & 9 jam & RVA \\
\hline 31 & Penetapan Renja SKPD. & 40 jam & BVA \\
\hline & & \\
\hline
\end{tabular}

\section{Proses Bisnis Usulan}

Proses bisnis usulan penyusunan Renja didapatkan dari sinkronisasi gap antara kondisi aktual dan kondisi yang sesuai dengan PERMENDAGRI Nomor 54 Tahun 2010 serta ISO 9001:2008 dan hasil dari analisa aktivitas dengan mengeliminasi proses yang tidak memberikan nilai tambah. Tabel 9 menunjukkan proses bisnis usulan yang lebih efektif dan efisien. 
Tabel 9 Proses Bisnis Usulan

\begin{tabular}{|c|c|c|c|}
\hline No & Proses & $\begin{array}{l}\text { Waktu } \\
\text { Proses }\end{array}$ & Pemilik Proses \\
\hline 1 & Pembentukan tim penyusun Renja. & 10 jam & Sekretaris \\
\hline 2 & Orientasi penyusun Renja. & $5 \mathrm{jam}$ & Sekretaris \\
\hline 3 & Penyusunan agenda kerja. & 2 jam & Sekretaris \\
\hline 4 & Mengumpulkan data dan informasi. & 18 jam & Kepala Bidang \\
\hline 5 & Mengolah data dan informasi. & 12 jam & Kepala Bidang \\
\hline 6 & Menganalisis gambaran pelayanan SKPD. & 22 jam & Kepala Bidang \\
\hline 7 & $\begin{array}{l}\text { Melakukan review hasil pelaksanaan Renja } \\
\text { SKPD tahun lalu berdasarkan Renstra SKPD. }\end{array}$ & 16 jam & $\begin{array}{c}\text { Kepala } \\
\text { subbagian } \\
\text { program }\end{array}$ \\
\hline 8 & $\begin{array}{l}\text { Isu-isu penting pelaksanaan tugas dan fungsi } \\
\text { SKPD. }\end{array}$ & 24 jam & Kepala Bidang \\
\hline 9 & Menelaah rancangan awal RKPD. & 27 jam & $\begin{array}{l}\text { Kepala } \\
\text { subbagian } \\
\text { program }\end{array}$ \\
\hline 10 & Merumuskan tujuan dan sasaran Renja. & 16 jam & Kepala Bidang \\
\hline 11 & $\begin{array}{l}\text { Menelaah usulan program/ kegiatan dari } \\
\text { masyarakat. }\end{array}$ & 15 jam & $\begin{array}{c}\text { Kepala } \\
\text { subbagian } \\
\text { program }\end{array}$ \\
\hline 12 & Merumuskan kegiatan prioritas. & 13 jam & $\begin{array}{c}\text { Kepala } \\
\text { subbagian } \\
\text { program }\end{array}$ \\
\hline 13 & $\begin{array}{l}\text { Menyajikan dokumen awal rancangan Renja } \\
\text { SKPD. }\end{array}$ & 56 jam & Kepala Bidang \\
\hline 14 & Verifikasi kelengkapan dokumen Renja. & $5 \mathrm{Jam}$ & $\begin{array}{c}\text { Kepala } \\
\text { subbagian } \\
\text { program }\end{array}$ \\
\hline 15 & Musrenbang desa/ kelurahan. & 50 jam & BAPPEDA \\
\hline 16 & Musrenbang kelurahan. & 50 jam & BAPPEDA \\
\hline 17 & Menelaah kebijakan nasional. & 3 jam & $\begin{array}{c}\text { Kepala } \\
\text { subbagian } \\
\text { program }\end{array}$ \\
\hline 18 & Menyempurnakan rancangan Renja SKPD. & 16 jam & Kepala Bidang \\
\hline 19 & Pembahasan forum SKPD. & 31 jam & $\begin{array}{l}\text { Kepala } \\
\text { subbagian } \\
\text { program }\end{array}$ \\
\hline 20 & $\begin{array}{l}\text { Menyesuaikan dokumen rancangan Renja } \\
\text { SKPD. }\end{array}$ & 132 jam & $\begin{array}{l}\text { Kepala } \\
\text { subbagian } \\
\text { program }\end{array}$ \\
\hline 21 & Menyiapkan forum SKPD. & 41 jam & $\begin{array}{l}\text { Kepala } \\
\text { subbagian } \\
\text { program }\end{array}$ \\
\hline 22 & Menyelenggarakan forum SKPD. & 5 jam & $\begin{array}{c}\text { Kepala } \\
\text { subbagian } \\
\text { program }\end{array}$ \\
\hline 23 & Penyusunan rancangan RKPD kabupaten/ & 80 jam & BAPPEDA \\
\hline
\end{tabular}




\begin{tabular}{|c|l|c|c|}
\hline 24 & $\begin{array}{l}\text { kota. } \\
\text { kelaksanaan Musrenbang RKPD kabupaten/ }\end{array}$ & 80 jam & BAPPEDA \\
\hline 25 & $\begin{array}{l}\text { Perumusan rancangan akhir RKPD kabupaten/ } \\
\text { kota. }\end{array}$ & 320 jam & BAPPEDA \\
\hline 26 & $\begin{array}{l}\text { Penetapan Perkada RKPD kabupaten/ kota. } \\
27\end{array}$ & $\begin{array}{l}\text { Verifikasi rancangan Renja SKPD dengan } \\
\text { RKPD. }\end{array}$ & BAPPEDA \\
\hline 28 & Pengesahan dan penetapan Renja SKPD. & 9 jam & Kepala Dinas \\
\hline
\end{tabular}

\section{Pembahasan}

Proses bisnis usulan diperoleh dari hasil analisis gap antara kondisi aktual yang mengacu pada timeline Renja DISKOPERINDAG dan kondisi yang mengacu pada PERMENDAGRI Nomor 54 Tahun 2010. Hasil dari gap tersebut adalah gabungan dari kondisi aktual dan kondisi yang mengacu pada PERMENDAGRI Nomor 54 Tahun 2010. Hasil gap tersebut disesuaikan dengan pemenuhan ISO 9001:2008 klausul 7.3 tentang desain dan pengembangan untuk menjamin konsistensi proses dan dilakukan penambahan proses jika terdapat syarat yang tidak terpenuhi. Hasil dari analisis gap antara kondisi aktual dan kondisi menurut PERMENDAGRI Nomor 54 Tahun 2010 serta ISO 9001:2008 akan dilakukan pemetaan pemilik proses. Proses bisnis tersebut akhirnya dilakukan analisis aktivitas untuk mengetahui proses yang memberikan nilai tambah dan yang tidak memberikan nilai tambah.

Perbandingan waktu proses adalah untuk melihat efisiensi antara kondisi hasil silang gap dan kondisi usulan. Waktu yang digunakan untuk membandingkan adalah waktu pada saat sudah terdapat hasil silang gap karena tujuannya adalah membandingkan proses bisnis yang sudah terintegrasi PERMENDAGRI Nomor 54 Tahun 2010 dan klausul 7.3 ISO 9001:2008. Kondisi aktual tidak dibandingkan dengan kondisi usulan karena pada kondisi aktual proses penyusunan Renja masih banyak terdapat gap. Pengukuran efisiensi waktu proses, maka perhitungan efisiensi antara proses bisnis hasil silang gap dan proses bisnis usulan adalah :

\section{Efisiensi Proses Hasil Silang=RVATotal Waktu Proses $=2441275=19,14 \%$ Efisiensi Proses Bisnis Usulan=RV ATotal Waktu Proses $=2441115=21,88 \%$}

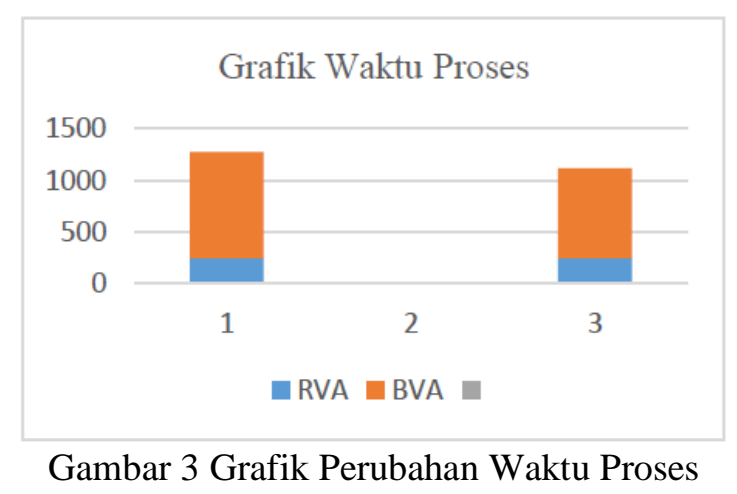

Gambar 3 menunjukkan perubahan waktu proses dimana pada saat proses bisnis disilangkan antara kondisi aktual dan kondisi ideal waktu proses penyelesaiannya adalah sebesar 1.270 jam, sedangkan setelah dilakukan analisa aktivitas dengan melakukan minimasi pada proses yang termasuk proses pendukung dan bisa digabung dengan proses yang lain maka waktu prosesnya menjadi 1.115 jam.

Pada proses bisnis hasil silang gap antara kondisi aktual dan kondisi menurut PERMENDAGRI efisiensinya adalah sebesar $19,14 \%$, sedangkan pada proses bisnis usulan dimana proses yang tidak memberikan nilai tambah telah dihilangkan efisiensi naik menjadi $21,88 \%$. Kenaikan sebesar 2,74\% berpengaruh terhadap waktu penyelesaian penyusunan Renja. Sehingga dengan adanya penambahan 
efisiensi maka akan berpengaruh terhadap waktu untuk menyelesaikan proses penyusunan tersebut yang akan berdampak pada output yang akan dihasilkan ke pelanggan berupa program yang akan dijalankan.

\section{Kesimpulan}

1. Identifikasi proses bisnis dilakukan dengan pengambilan data primer dan data sekunder. Sehingga didapatkan data proses bisnis aktual untuk penyusunan Renja terdapat 11 proses dan proses bisnis menurut PERMENDAGRI Nomor 54 Tahun 2010 terdapat 21 proses.

2. Gap proses bisnis diidentifikasi dengan melakukan perbandingan antara proses penyusunan Renja aktual dan proses penyusunan Renja menurut PERMENDAGRI Nomor 54 Tahun 2010. Hasil gap menunjukkan bahwa banyak terdapat gap yang terjadi sehingga harus dilakukan penambahan proses sehingga dari hasil gap didapatkan 30 proses bisnis penyusunan Renja.

3. Penyelesaian permasalahan ketidaktepatan waktu penyusunan Renja DISKOPERINDAG dilihat dari permasalahan yang dianalisis menggunakan 5 Why's dan diagram sebab-akibat, maka permasalahan diselesaikan dengan melakukan perbaikan pada proses bisnis penyusunan Renja dimana perbaikan mengacu pada PERMENDAGRI Nomor 54 Tahun 2010 dan klausul 7.3 ISO 9001:2008.

4. Perbaikan proses bisnis kritis dilakukan dengan melihat gap yang terjadi kemudian dilakukan analisis aktivitas untuk melihat proses yang memberikan nilai tambah dan proses yang tidak memberikan nilai tambah. Pada proses bisnis hasil gap didapatkan jumlah proses yang termasuk RVA sebanyak 12 proses, BVA sebanyak 15 proses, dan NVA sebanyak 3 proses. Streamlining yang digunakan adalah value-added assessment untuk proses yang tergolong BVA, dan duplication elimination untuk proses yang tergolong NVA.

5. Perbaikan proses bisnis penyusunan Renja berdasarkan PERMENDAGRI Nomor 54 Tahun 2010 dan ISO 9001:2008 klausul 7.3 dan menghasilkan rancangan SOP usulan penyusunan Renja yang terdiri dari 27 proses dan 20 instruksi kerja.

\section{Daftar Pustaka}

[1] S. Fahmi, “Analisis Perencanaan Strategi Pemasaran Pada Pt. Hapeel Pharmindo,” J. Manaj. dan Bisnis Indones., vol. 2, no. 3, pp. 344-363, 2015.

[2] G. Padma Arianie and N. Budi Puspitasari, "Perencanaan Manajemen Proyek Dalam Meningkatkan Efisiensi Dan Efektifitas Sumber Daya Perusahaan (Studi Kasus: Qiscus Pte Ltd),”J@ti Undip J.Tek. Ind., 2017.

[3] D. H. Wibowo, Z. Arifin, and . Sunarti, "Analisis Strategi Pemasaran Untuk Meningkatkan Daya Saing UMKM (Studi pada Batik Diajeng Solo),” J. Adm. Bisnis, vol. 29, no. 1, pp. 59-66, 2015.

[4] Mentri/sekretaris negara Republik Indonesia, "Undang-Undang Republik Indonesia Nomor 25 Tahun 1992 Tentang Perkoperasian," Lembaran Negara Republik Indones., 1992.

[5] R. Purwaningsih and P. Kusuma Damar, "Analisis Faktor-faktor yang mempengaruhi Kinerja Usaha Kecil dan Menengah (UKM) dengan Metode Structural Equation Modeling (Studi kasus UKM berbasis Industri Kreatif Kota Semarang)," E-Journal Undip, 2015.

[6] S. B. Utomo, "Business Process Improvement ( Bpi ) Proses Pengadaan Barang Non-Part Dengan Membangun E-Catalog ( Studi Kasus Di Pt . Tmmin ),” Semin. Nas. Sist. Inf. Indones., no. November, 2018.

[7] C. Öberg, "The role of business networks for innovation," J. Innov. Knowl., vol. 4, no. 2, pp. 124-128, 2019.

[8] B. R. Chabowski and S. Samiee, "The Internet and the International Management Literature: Its development and intellectual foundation," J. Int. Manag., vol. 26, no. 1, pp. 1-10, 2020. 
[9] A. R. Saputro, M. Indriayu, and S. A. T. Pendidikan, "PENGARUH KEAKTIFAN BERORGANISASI DAN PRESTASI BELAJAR TERHADAP KESIAPAN KERJA MAHASISWA PROGRAM STUDI PENDIDIKAN EKONOMI ANGKATAN 2013-2016 UNIVERSITAS SEBELAS MARET SURAKARTA," Pendidik. Ekon. Fak. Kegur. dan Ilmu Pendidik. Univ. Sebel. Maret Surakarta, vol. 28, no. 2, pp. 250-250, 2016.

[10] A. T. Wibowo, N. U. Handayani, and S. Si, "Desain Penerapan Lean Supply Chain Management Pada Proses Loading Pupuk in Bag Pada Pt . Petrokimia Gresik," 2017.

[11] sis. binus. ac. Id, "Fishbone Diagram," https://sis.binus.ac.id/2017/05/15/fishbone-diagram/, 2017. [Online]. Available: https://sis.binus.ac.id/2017/05/15/fishbone-diagram/.

[12] Nasir, "FISHBONE STRATEGY IN TEACHING ENGLISH IN INDONESIA: A TOOL," $J$. Chem. Inf. Model., vol. 53, no. 9, pp. 1689-1699, 2019.

[13] S. Indonesia, "Analisis Akar Masalah dengan Fishbone Diagram," 1, 2016. [Online]. Available: http://shiftindonesia.com/analisa-akar-masalah-dengan-fishbone-diagram/.

[14] H. Anastasiya and F. Terje, "Navigating through institutional complexity: adoption of a process view in functional organizations," Bus. Process Manag. J., vol. 26, no. 2, pp. 593-612, Jan. 2019.

[15] H. Junaid, A. Naveed, M. S. U.R., and A. Adeel, "Application of formal methods to modelling and analysis aspects of business process reengineering," Bus. Process Manag. J., vol. 26, no. 2, pp. 548-569, Jan. 2019.

[16] P. Mikalef, I. O. Pappas, J. Krogstie, and P. A. Pavlou, "Big data and business analytics: A research agenda for realizing business value," Inf. Manag., vol. 57, no. 1, 2020.

[17] S. Adesola and T. Baines, "Developing and evaluating a methodology for business process improvement," Bus. Process Manag. J., vol. 11, no. 1, pp. 37-46, 2005.

[18] M. Dimitrova, S. I. Chia, M. A. Shaffer, and C. Tay-Lee, "Forgotten travelers: Adjustment and career implications of international business travel for expatriates," J. Int. Manag., vol. 26, no. 1, 2020.

[19] S. D. Larasati, S. A. Wicaksono, and N. H. Wardani, "Perbaikan Proses Bisnis Menggunakan Metode Business Process Improvement ( BPI ) ( Studi Pada Bagian Riset Pemasaran dan Pusat," J. Pengemb. Teknol. Inf. dan Ilmu Komput. Univ. Brawijaya, vol. 1, no. 11, pp. 1425-1432, 2017.

[20] A. Lumumba, G. I. Sukoco, T. Ayuningsih, I. F. Rahayu, and N. S. Toharoh, "Analisis Proses Bisnis Layanan Triple Play Menggunakan Pendekatan Business Process Improvement (BPI) (Studi Kasus di PT TELKOM INDONESIA),”J. Manaj. Indones., vol. 16, no. 3, p. 205, 2017.

[21] F. Andika, M. Kholil, T. Industri, and U. M. Jakarta, "Bussiness Process Improvement Sebagai Dasar Perbaikan Proses Penerbitan Dokumen Work Completion Certificate ( WCC ) dengan Menggunakan Metode Streamlining di PT XYZ,” J. Ilm. PASTI, vol. VI, no. 1, pp. 50-57, 2017.

[22] R. Fadhillah, "Usulan Perbaikan Bisnis Proses Pada Divisi Production Engineering Di Industri Otomotif Dengan Menggunakan Pendekatan Business Process Improvement," Universitas Indonesia, 2009.

[23] W. Prihatmadji, "Peningkatan dan Perbaikan dari Temuan Audit External ISO 9001 di LP3I College," Maj. Ilm. Bijak, vol. 16, no. 1, pp. 53-65, 2019.

[24] Novalino, S. Widaningrum, and A. N. Aisha, "Perancangan Standard Operating Procedure Untuk Menyusun Rpjmd Kabupaten Bandung Dengan Memenuhi Peraturan Menteri Dalam 
Negeri Dan Iso 9001:2008 Klausul 7.3 Berdasarkan Metode Business Process Improvement,” J. Rekayasa Sist. dan Ind., vol. 2, no. 01, pp. 8-12, 2015.

[25] N. Y. S. Indra Fahrizal, Ismiarta Aknuranda, "Analisis Dan Perbaikan Proses Bisnis Menggunakan Metode Business Process Improvement ( BPI ) ( Studi Kasus: PT . Wonojati Wijoyo )," J. Pengemb. Teknol. Inf. dan Ilmu Komput., vol. 2, no. 12, pp. 6201-6209, 2018. 